\title{
THEORETICAL AND LEGAL CHARACTERISTICS OF ECONOMIC CRIMES OF A TRANSNATIONAL NATURE
}

\author{
Vadym Popko', Yevgen Popko
}

\begin{abstract}
The article examines the theoretical and legal foundations of economic crimes of a transnational nature formed under the influence of globalisation processes in the world, the growth of international crime and other factors. The author provides a conceptual description of transnational crime as the main category of transnational criminal law, including economic crimes. Scientific views of domestic and foreign scientists on the nature of crimes of an international nature, including criminal acts in the economic sphere are analysed; the most dangerous and widespread economic crimes are characterised. Attention is paid to the legal regulation of these relations, universal and regional conventions, other sources. The authors justify the need to criminalise transnational economic crimes in national law, regardless of whether a particular state is a party to international conventions adopted by international organisations. The authors pay special attention to the characteristics of the subjects of the crime and reveals the debatable nature of their definition, in particular, analyse the problematic nature of the recognition of a legal entity as a subject of crime. The authors use a conceptual approach to clarifying the subject of study, which determines the reasonability of theoretical research, and modern principles of scientific methodology: the principle of scientific pluralism, impartiality, comprehensiveness of research, historicism, complexity and others. A modern requirement in the methodology of science is the rejection of methodological monism, which has long been dominant in theoretical and historical studies of social (including legal) phenomena and the rejection of the ideology of scientific knowledge, which provides an objective, unbiased attitude to any legal phenomena, legal systems, etc. The purpose of the article is to provide theoretical and legal characteristics of international crime in the economic sphere, identify the transnational nature of these crimes, clarify the state of legal regulation of these relations at the international level, as well as international cooperation to combat these crimes. Based on the study and theoretical generalisation of the research topic, the authors emphasise the following conclusions: modern world problems are global in nature; economic crime transcends borders and becomes international; economic crimes of a transnational nature are recognised as socially dangerous acts that encroach on the system of social relations in the field of financial and credit, investment, information, trade, etc. activities, and have a transnational nature, i.e. go beyond one state; countering economic crimes of a transnational nature is within the internal competence of states, but international cooperation in this area also has an objective basis; the legal basis of international cooperation of states are international legal anti-criminal conventions, which define the criminal acts and obligations of states to criminalise economic crimes and provide legal assistance in criminal proceedings, in particular in extradition and transfer of accused and convicted persons, disposal of confiscated property, joint investigation and other issues.
\end{abstract}

Key words: globalization, economic crimes, transnational criminal law, domestic law, internal legislature, convention.

\section{JEL Classification: K14, K33}

\section{Introduction}

Globalisation is a comprehensive process that affects economic, political, informational, cultural, social, and legal trends, and involves an increase in the level of interaction both within individual states and between

\footnotetext{
Corresponding author:

${ }^{1}$ Taras Shevchenko National University of Kyiv, Ukraine.

E-mail: vadympopko@gmail.com

ORCID: https://orcid.org/0000-0001-8358-7721

${ }^{2}$ Taras Shevchenko National University of Kyiv, Ukraine.

E-mail: ep@pbp.ua

ORCID: https://orcid.org/0000-0002-7417-7584
}

states. The intensification of these processes contributes to both the expansion of the functions and areas of responsibility of the state and the inability to effectively cope with the challenges of time. Goods, capital, people, information, weapons, drugs, etc., became easy to cross 
state borders, which contributed to the penetration of transnational networks in almost all spheres of human activity (Gadzhiev, 2002) by using favourable market conditions (both shadow and legal ones) in order to obtain economic benefits (Chuprova, 2009). The Eleventh United Nations Congress on Crime Prevention and Criminal Justice (2005) notes that globalisation and technological development have brought many benefits to society, but they have also opened up new opportunities for crime and for criminals."

Nowadays, transnational economic crime has become significant in the world and has become a global business, which brings huge profits to organised criminal groups and really threatens the statehood of many countries (Gros, 2003). The so-called economic crimes became especially dangerous (Streltsov, 2000). Indeed, crime generates huge revenues. Despite the lack of accurate estimates, it is known that these revenues pose a global threat to the economic security of many countries and the global financial system as a whole (Zelinskaia, 2017).

International crimes such as smuggling, robbery, corruption and bribery of state, public, party figures and elected officials, counterfeiting money and securities, money laundering, false bankruptcy, illegal entry into legal business, etc., have become large-scale and more sophisticated. Crimes committed in the economic sphere at the national and international levels, together, began to occupy a leading place (after drug crime) in the total number of crimes of an international nature. Combating this crime requires the efforts of the international community, as the consequences of these crimes are manifested across national borders.

Economic crimes of an international nature are increasingly becoming transnational in nature, constantly improving their forms and methods and expanding the scope of their activities, which requires theoretical, scientifically sound and critical analysis of these processes. Given that the problem of globalisation of crime in the economic sphere at the beginning of the 21 st century has become unprecedented, it cannot be solved within the framework of limited nationalstate means and methods. In order to combat these crimes, international conventions, resolutions and recommendations are adopted, international forums and congresses are convened, and the activities of international organisations are intensified.

Recently, the interest in the study of general theoretical and applied problems of combating transnational crime has significantly increased in the science of international criminal law. Scientists study the phenomenon of crime in various fields and the impact of globalisation in this matter, examine causes and social preconditions, summarise the international experience of cooperation in this area, study national criminal justice systems and the system of international criminal law. Researchers pay special attention to the legal nature of international crimes and crimes of an international nature (conventional crimes, extradition crimes, transnational crimes), clarification of the qualifying features of the crime and its subjects; certain types or categories of crimes of an international nature are actively investigated (terrorism, piracy, drug trafficking, human trafficking, illegal migration, crimes in the environmental sphere, etc.).

Domestic and foreign scholars in the system of international criminal law distinguish an autonomous sub-branch, called transnational criminal law, which is based on the separation of the subject of legal regulation of public relations (J. Albanese, N. Boister, A. Bossard, H. Zharovska, N. Zelinskaia and etc.). Transnational criminal law requires the study of the categorical apparatus, the source base, the subjects of the crime, its qualifiers, the responsibility for the act and the classification of types of crimes on various grounds. According to the criterion of the generic object of encroachment, a group of transnational crimes committed in the economic sphere is distinguished, but their study has so far received little attention and concern mostly criminology issues.

\section{Transnational crime - category of transnational criminal law}

Under the influence of globalisation factors, primarily economic, as well as increasing influence of international organisations, supranational entities, the development of international law, its fundamental principles, expanding the range of subjects of international relations, unprecedented growth of transnational crime, the emergence of new crimes and increase in their number, has formed a new area of legal regulation - transnational criminal law, which is an autonomous part of international criminal law (Popko, 2020). The answer to the challenge of globalisation of crime should be to accelerate the development of international criminal law, the prospects of which are associated with the political integration of the world community in a criminal policy entity that has universal jurisdiction and can radically solve the problem of effective crime control" (Kibalnik, 2003).

Transnational criminal law is a sub-branch of international criminal law, allocation of which into an independent autonomous part took place in the late 20 th - early 21 st centuries. Significant differences in the sub-branches of international criminal law indicate the de facto separation of transnational criminal law into a separate system, which has its own subject, method, tasks, principles, sources and categorical apparatus. The main category of transnational criminal law is transnational crime, which is the main criterion for distinguishing this sub-branch from, in the words of British scholar Neil Boister, "basic international criminal law" (Boister, 2012). This has been scientifically 
substantiated in a number of works by domestic and foreign scientists (Boister, Zharovska, Zelinskaia) and is characterised by a number of qualifying features. It should be noted that the analysis of the provisions of international acts indicates that in the vast majority they do not contain a definition of this phenomenon, and in the absence of a general concept of transnational crime introduced special, such as corruption as a transnational crime (Gravina, 2015), drug falsification as a transnational crime (Demchenko, Solovyov, 2014) and others.

The most important conceptual feature of a transnational crime is transnationality, which should be interpreted in accordance with Art. 3 para. 2 of the UN Convention against Transnational Organised Crime of 2000. According to this article, a transnational crime is considered as a) an act committed in more than one state; b) the offence is committed in one state but a substantial part of its preparation, planning, direction or control takes place in another state; c) it has been committed in one state but with the participation of an organised criminal group carrying out criminal activity in more than one state; d) it is carried out in one state, but its significant consequences take place in another state. Transnational crime is characterised as an act (it can be both action and inaction) committed by the subject of the crime with a "foreign element" (the territory of the crime may be foreign, the accomplices may be foreigners, etc.), which threatens important social relations (security, life and human health, property, funds, etc.), or harms these relationships. It should be borne in mind that criminal consequences usually occur for more than one state.

In contrast to the jurisdiction over major international crimes, which according to Article 5 of the Rome Statute of the International Criminal Court is "limited to the most serious crimes of concern to the entire international community", jurisdiction over transnational crimes is purely national (Hnatovskyi, Tropin), as international criminal jurisdiction in such cases is absent. Transnational crimes are usually committed by private individuals, for profit or other private gain, and prosecution does not require the institutionalisation required by individuals for committing an international crime in the form of an international criminal tribunal.

\section{Characteristic of the economic crimes of a transnational nature}

In contrast to transnational crimes of a political nature (for example, political orientation is inherent in some terrorist acts), which should be considered as an exception (Zelinskaia, 2003, Karpets, 1988), when characterising transnational crimes it is advisable to pay attention to their economic orientation. According to researchers, "most transnational criminal activity is motivated by a desire for personal economic gain"
(Boister, 2012). Crimes in the economic and financial spheres related to false bankruptcy, concealment of income, tax evasion, smuggling, and the shadow economy are becoming increasingly dangerous. Scholars view transnational organised crime as an economic phenomenon by nature, arguing that it is essentially one of the sectors of the economy that produces and supplies illegal goods and services or illegal goods to world markets, and invests the resulting capital in including in the legitimate spheres of economics (Repetskaya, 2001). It is argued that transnational organised crime can be seen as the functioning of criminal organisations and communities that have an extensive network in other countries that use international connections to carry out global illicit transactions involving the movement of information, money, and physical objects, people, other tangible and intangible assets across national borders in order to use favourable market conditions in one or more foreign countries to obtain significant economic benefits, as well as to effectively evade social control through corruption, violence and the use of significant differences in criminal justice systems of different countries (Repetskaya, 2001). A similar view is expressed by other scholars, who note that using corrupt connections, modern organised crime in the economic sphere is transnational in nature, criminal organisations create transnational companies engaged in criminal business in various sectors of the economy. Being associated with illegal transactions for the movement across state borders of tangible and intangible assets that bring significant economic benefits, using the favourable market conditions of other countries, significant differences in criminal justice systems of different countries, modern communication technologies, banking electronic payment systems, penetrate the legal economy of other countries through corruption and violence, the greatest interest in these organisations is the fuel and energy complex (Pohoretskyi, 2007).

Economic transnational crime is most often associated with the financial and credit system, the consumer market, the manufacture and circulation of unlabelled products, the illicit trafficking of precious metals and stones, etc., which causes significant material damage. It should be noted that nowadays there are virtually no criminal organisations whose activities are related to only one area of criminal business. Given the fact that the main goal of any organisation is to obtain economic benefits, without a doubt, any transnational criminal organisation uses modern financial and information technologies to launder the proceeds, including through the commission of cybercrime. Minimising the risk of exposure requires establishing corruption links.

Economic crimes of a transnational nature are conventional, i.e. their normative enshrinement is enforced in international legal acts, primarily anti- 
criminal conventions (Boister, Werle, Zelinskaia, Cassese); they are characterised by diversity and they can be classified according to different criteria. The specific characteristics of economic crimes are given in numerous anti-criminal conventions aimed at regulating specific legal relations, as a single codified act in this area has not existed yet.

Thus, in international criminal law, among the numerous crimes of an international nature, there is a group of economic crimes of a transnational nature, the separation of which is indicated by foreign and domestic scholars (Adelkhanian, Andrushko, Boister, Butkevych, Karpets, Skrylnyk). All of them emphasise the need to criminalise these crimes in national law, given their great public danger.

Economic crimes of a transnational nature are unlawful acts, harm citizens, businesses or states and are committed for selfish purposes; such crimes are always planned, always intentional, but can sometimes be committed through negligence. Economic crime is a crime committed by corporations against other corporations, the state economy, or consumers (Luneev, 1999). This is also emphasised by Swedish researchers: economic crimes should include acts that have economic benefit as their motive, which is also characterised by duration, regularity, carried out in the framework of legal economic activity (Svensson, 1987).

This category of economic crimes is characterised by the crossing of the border by criminals or the manifestation of the results of their illegal actions outside the country, which can be both physical and virtual, i.e. consist in the transfer of information. The concept of economic crime of a transnational nature is multifaceted, as it includes not only violations of criminal law but also accompanying violations of other branches of law - administrative, financial, customs, civil, and so on. Such a crime is characterised as an act committed by the subject of the crime, in the presence of a "foreign element"; has a transnational character, i.e. the criminal consequences of which extend to more than two states; liability arises not only on the basis of international agreements, but also under national law.

Regarding the subjects of economic crimes, their range is not constant and may depend on various circumstances, including the level of development of international financial and economic relations (raising the question of the international legal personality of transnational corporations), the types and means of organising human communities in state (Hnatovskyi, 2019). The most difficult issue is the recognition of a legal entity as a subject of crime (Inogamova-Khegai, 2004). Despite the problematic nature of the provisions on the recognition of a legal entity as a subject of a transnational crime (in particular, the thesis on the recognition of the subjective guilt of a legal entity is problematic), the rules of anti-criminal conventions (Article 5 of the International Convention for the
Suppression of Terrorist Financing 1999, Art. 26 UN Convention against Corruption 2003, Article 10 of the UN Convention against Transnational Organised Crime 2000, etc.) allow criminal liability of legal entities.

In international criminal law, the generally accepted thesis is the recognition of an individual as the main subject of criminal liability for the commission of a transnational crime. The actions of individuals constitute a transnational criminal act, and the commission of an economic crime of a transnational nature by a collective entity (for example, an organised group) requires the establishment of the role of each person in the crime. This does not contradict the principle of individual criminal responsibility, because the collective nature of such acts does not exempt from the need to address the issue of individual criminal responsibility (Inogamova-Khegai, 2004). Specific penalties are defined in national law in accordance with the peculiarities and traditions of legal systems, while the rules of transnational criminal law do not provide for sanctions for the crime. They do not contain specific characteristics of the person, for example, do not establish the age for being subjected to criminal liability. Sources in such cases refer to domestic law. Transnational convention crimes are committed by subjects on their own grounds, outside the direct connection with the policy of a state (Hnatovskyi, 2019) and such subjects are liable under national criminal law on the basis of criminalisation of an international convention.

Transnational economic crimes are characterised by the presence of collective actors, i.e. their multiplicity, which involves the commission of a crime by several persons or an organised group. There are a large number of organised criminal communities, which differ in size, areas of specialisation, area of operation and other parameters. Transnational criminal organisations are different, have different histories of origin and spread, engage in different types of criminal activity, different scales of their activities" (Zharovska, 2019). They are referred to by different terms: "transnational criminal corporations" (Ivanov, 1999), "international criminal organisations" (Godson, Olson, 1995), "transnational organised criminal groups" (Shelley, 1995), most criminologists use the term "transnational criminal organisations" (Bilenchuk, 1999; Verbenskyi, 2010). It should be noted that these differences are mostly terminological in nature, the characteristics of these subjects usually coincide.

It should be noted that the UN Convention against Transnational Organised Crime of 2000 uses the term "organised criminal group". The Convention defines "organised criminal group" as a structured group of three or more persons that exists for a specified period of time and acts in concert to commit one or more serious crimes or crimes recognised as such under the Convention, in order to receive, directly or indirectly, financial or other tangible benefits. A "structured group" should be 
defined as a group that was not formed by chance to commit a crime immediately and in which the roles of its members are not necessarily formally defined, the continuity of membership is discussed, or a developed structure is established. Given that transnational crimes are characterised by multiple subjects (the commission of a crime by several persons or an organised group), the collective nature of such acts does not relieve the need to address the issue of individual criminal responsibility (Buergenthal, Maier, 2001).

The most powerful of the transnational criminal groups today are: the Colombian cocaine cartels; Chinese criminal groups - triads; Sicilian Mafia (Cosa Nostra), Neapolitan Camorra, Calabrian Ndrangheta. The main group of collective actors of transnational organised crime are criminal organisations and communities that have an extensive network of branches in different countries and are characterised by a high degree of organisation on a family or ethnic basis, which greatly contributes to solidarity of members, increase their responsibility for security, ensure discipline and subordination within the links and in the organisation as a whole (Verbensky, 2009).

Describing the subjects of transnational crime, L. Shelley draws attention to the spheres of collective activity of the subjects of criminal activity, because "at the beginning of the 21 st century subjects of transnational organised crime are involved in a wide range of criminal activities, their criminal interests include traditional types of organised crime (drug and arms trafficking, human trafficking, smuggling), which are combined with industrial and technological espionage, financial manipulation, stock market, counterfeiting of high-tech products, etc. Corruption and links with political circles, control of law enforcement and the judiciary, and money laundering through offshore are used as a means of committing such criminal activity (Shelley, 1995).

\section{Conventional and institutional mechanisms of combating economic crimes of a transnational nature}

The Convention mechanism, established by the international community, ensures the cooperation of states in combating various types of transnational economic crime, despite the diversity of economic systems in the modern world and differences in the qualification of economic crimes in different legal systems. The conventional mechanism of international cooperation in the fight against economic crimes of a transnational nature should be understood as a set of international legal acts concluded at international conferences (universal and regional) and regulating relations between states in combating these crimes.

The beginning of the formation of the Convention Mechanism for International Cooperation in
Combating Economic Crimes was laid by the Geneva Convention for the Suppression of Counterfeiting Currency of 1929, concluded at the initiative of the League of Nations. States parties have committed themselves in the fight against counterfeiting not to distinguish between counterfeiting of domestic and foreign banknotes and securities and to punish criminals with the same principle (Article 5). With the development and emergence of new forms of economic crime, the reaction of states was the adoption of the Council of Europe Convention on Laundering, Search, Seizure and Confiscation of the Proceeds from Crime of 1990, in which the definition of "money laundering" (Article 6) coincides with the first in Article 3 of the 1988 UN Convention against Illicit Traffic in Narcotic Drugs and Psychotropic Substances, which preceded chronologically the issue of money laundering illegally obtained from the sale of narcotic drugs and other substances. According to Article 3 of this Convention, the legalisation of income means:

- conversion or transfer of property, if it is known that such property was obtained as a result of any offence...; - concealment of the true nature, source, location, method of disposal, transfer, real rights in respect of property or its belonging, if it is known that such property was obtained as a result of an offence...;

- acquisition, possession or use of property, if at the time of its receipt it was known that such property was obtained as a result of an offence...;

- participation in, involvement in, or conspiracy to commit any offence or offences recognised in accordance with this article, attempts to commit such an offence or offences, and aiding, abetting, facilitating or advising in the commission thereof.

Thus, the term "money laundering" refers to a process that allows you to mask the illegal origin of proceeds of crime. Money laundering is a system-forming element and at the same time a condition and consequence of organised crime.

The provisions of this Convention were further developed in the 2000 UN Convention against Transnational Organised Crime and in the Council of Europe Convention on Laundering, Search, Seizure and Confiscation of the Proceeds from Crime and on the Financing of Terrorism in 2005. These conventions provide for international legal action for combatting the legalisation of criminal proceeds, in particular States Parties have undertaken to criminalise the crime; to adopt relevant laws on the procedure for searching for the seizure and confiscation of illegally obtained funds, to consolidate the right of access of law enforcement agencies to banking operations that allow for the timely detection of such crimes.

No less dangerous economic crime of a transnational nature is corruption, the criminalisation of which is provided for in the UN Convention of 2000 and the UN Convention against Corruption of 2003. The 
Convention against Corruption is a basic international legal document based on a comprehensive approach to the socio-legal nature of corruption, and is concerned about the relationship with "other forms of crime, including organised crime and economic crime, including money laundering" (Preamble). The Convention further believes that "corruption is no longer a local problem, but has become a transnational phenomenon that affects the societies and economies of all countries, which makes international cooperation in preventing and controlling corruption crucial." Scholars characterise corruption as a transnational phenomenon, which consists in bribing foreign officials in order to gain the opportunity to conduct or continue economic activity in any country, or to gain some inappropriate advantage (Repetskaya, 2005). According to the latest sources, corruption combined with money laundering and illicit enrichment fall under the category of organised crime. The anticorruption mechanism in today's conditions is being developed and improved through the participation of international organisations, including the UN (Hrynchak, Zeman, Kohutych, Marin, 2019). The Convention against Corruption is used to prevent, investigate and prosecute corruption, as well as to suspend operations (freeze), arrest, confiscate and recover proceeds of crime under the Convention. Such crimes include: bribery of national public officials, bribery of foreign public officials and officials of public international organisations, theft, misappropriation or other misuse of property by public officials, abuse of power, abuse of office, illicit enrichment, etc.

A special place in the Convention mechanism of cooperation between states in combating economic crimes is occupied by the UN Convention against Transnational Organised Crime 2000, which defines the main types of transnational crime related to economic activity: money laundering, intellectual property infringement, insurance fraud, false bankruptcy and other. The list of transnational economic crimes defined by the Convention cannot be considered exhaustive, as the features of a transnational crime are inherent in the composition and other illegal acts inherent in this phenomenon (smuggling, counterfeiting, etc.). The 2000 Convention contains preventive norms that oblige states to "develop and evaluate the effectiveness of national projects, as well as to identify and implement best practices and policies aimed at preventing transnational organised crime" (Article 31, para. 1). And further specifically: the provisions of the Convention provide for the prevention of abuse by organised criminal groups of bidding procedures conducted by public authorities, subsidies and licenses issued by public authorities for commercial activities. The Convention obliges States parties to establish public registers of legal entities and individuals, their management and financing, and to establish a national register of persons deprived of the right to hold the office of head of legal entities.

There are a number of other conventions aimed at combating transnational economic crimes, in particular the basic document in the fight against cybercrime for European countries is the Council of Europe Convention on Cybercrime 2001, which is the basis for drafting relevant legislation in European countries. The Organisation for Economic Co-operation and Development (OECD) concluded in 1997 a Convention to Combat Bribery of Foreign Public Officials in International Business Transactions; in 1883, the Paris Convention for the Protection of Industrial Property (last revised October 2, 1979) was adopted, which aims to protect any intellectual property and to generate income from its use.

The existing regulatory framework, which is not perfect (for example, there is no universal regulation at the international level on smuggling, although the Convention on the Suppression of Alcohol Smuggling was adopted in 1925), is a conventional mechanism for combating transnational economic crimes, complemented by an institutional mechanism and requires law enforcement activities. One of the main activities of the United Nations is to create a regulatory framework for effective cooperation between states in combating economic crime. As a coordinating center for cooperation between UN states, it promotes the interaction of international and national law, especially international criminal law with national law. The institutional mechanism includes the activities of UN bodies, regional international organisations and specially created structures to combat crime. The main body for the coordination of economic activities of the $\mathrm{UN}$ and specialised agencies related to the UN is the UN Economic and Social Council (ECOSOC). Within the framework of the UN, the Office for Drugs and Crime functions fruitfully, within the framework of the European Union, the control over the implementation of legal acts in the field of anti-corruption is entrusted to a special pan-European EU body - GRECO. In the process of cooperation, the interaction of the states is carried out on the issues of extradition / transfer of prisoners or convicted persons, provision of legal assistance, information exchange, technical assistance and other criminal procedure issues.

\section{Conclusion}

The main scientific conclusions and generalisations are as follows:

1. Achievements of the 21 st century have significantly changed the world, creating the latest technologies, discoveries in the field of basic and applied science, economics, culture, art, etc., but there are problems that are global in nature, the solution of which requires the efforts of all states. One such problem is crime that 
transcends borders and becomes international. Crimes committed in the national and international economy are defined as economic crimes of an international (transnational) nature (transnational crimes).

2. Countering economic crimes of a transnational nature is within the internal competence of states, but international cooperation in this area also has an objective basis, as crime is now internationalising. It is gaining more and more foreign and international elements, i.e. the commission of criminal acts on the territory of two or more states, attempts by criminals to flee from justice abroad, the sale of abductees, money laundering, computer crime for which there are no national borders. Thus, the problem of international economic crime is becoming more and more global.

3. International criminal law and its subbranch - transnational criminal law, constitute a kind of legal basis for international cooperation in combating economic crimes of an international nature in terms of detecting and classifying illegal acts committed by entities to the category of crimes of international nature in international economic relations, establishing responsibility of international law and the punishment of persons guilty of such crimes.

4. Economic crimes of a transnational nature are recognised as socially dangerous acts that encroach on the system of public relations in the field of financial and credit, investment, information, trade, and other activities; have a transnational character, i.e. go beyond one state; protected by states and the international community.
5. The convention and institutional mechanisms for combating transnational economic crimes involve the criminalisation of these crimes and the set of obligations assumed by the states' parties to universal and regional conventions. The obligations include international cooperation in criminal procedure, in particular in matters of extradition / transfer of accused and convicted persons, disposal of confiscated property, joint investigation and other issues of mutual legal assistance.

6. The adoption of a significant number of international legal instruments in a relatively short period of time indicates: the global nature of the problem and the need for its regulation; awareness of states of the impossibility to independently counteract transnational economic crimes only through domestic regulation; the need for international cooperation to successfully combat crimes such as money laundering, corruption, smuggling, counterfeiting of money and securities, illicit trafficking in narcotic drugs and psychotropic substances, tax evasion, false bankruptcy, illegal use of trademarks and service marks, etc.

7. An important task to be solved by the world community, with the preventive purpose of preventing the commission of economic crimes of a transnational nature using global information and telecommunication networks by the criminal community, is to develop a universal legal framework for international cooperation in this area. It can be both a codified normative legal act and a set of normative documents aimed at regulating relations in this area.

\section{References:}

Adelkhanian, R. A. (2002). Prestupnost deianiia po mezhdunarodnomu ugolovnomu pravu [Criminality of an act under international criminal law]. Moscow: MZ-press.

Andrushko, A. V. (2020). Robocha programa "Mizhnarodne kryminalne pravo" dlia studentiv za napriamom pidhotovky "Pravo", za spetsialnistiu "Pravoznavstvo" [Work program "International Criminal Law" for students majoring in "Law", speciality "Jurisprudence"]. Uzhhorod: State Higher Educational Institution UzhNU.

Bilenchuk, P. D., Erkenov, S. E., \& Kofanov, A. V. (1999). Transnatcionalnaia prestupnost: sostoianie i transformatciia [Transnational crime: state and transformation]. Kyiv: Atika.

Verbenskyi, M. H. (2009). Subiekty transnatsionalnoi orhanizovanoi zlochynnosti ta yikh kharakterystyka [Subjects of transnational organized crime and their characteristics]. Pravo i Suspilstvo, vol. 6, pp. 77-83.

Verbenskyi, M. H. (2010). Transnatsionalna zlochynnist: kryminolohichna kharakterystyka ta shliakhy zapobihannia [Transnational crime: criminological characteristics and ways of prevention]: dissertation ... Dr. jurid. science: 12.00.08 / Dnipropetrovsk State University of Internal Affairs. Dnipro.

Gerhard Werle (2011). Printcipy mezhdunarodnogo ugolovnogo prava [Principles of international criminal law]: textbook. Transl. from English. S. V. Sayapina. Odessa: Feniks.

Boister, N. (2012). An introduction to Transnational Criminal Law. Oxford: University Press.

Buergenthal, T., \& Maier, H. G. (2001). Public international law in a nutshell. West group. St. Paul.

Gadzhiev, K. S. (2002). Vvedenie v geopolitiku [Introduction to Geopolitics]: college textbook / second edition, add. Moscow: Logos.

Gravina, A. A. (2015). Transnatcionalnaia koruptciia kak sostav mezhdunarodnogo prestupleniia [Transnational corruption as an international crime. Zhurnal rossiiskogo prava: nauchno-prakticheskoe izdanie, vol. 12, pp. 87-100.

Demchenko, I., \& Solovyov, O. (2014). Poperedzhennia poshyrennia falsifikovanykh zasobiv na mizhnarodnomu ta natsionalnomu rivni [Prevent the spread of counterfeit funds at the international and national levels]. Kyiv: Novyi Druk. 
Report of the Eleventh Congress on Crime Prevention and Criminal Justice of the United Nations on Crime Prevention and Criminal Justice. Bangkok, April 18-25, 2005. - UN Doc. A/CONF.203/18. Available at: http://www.un.org./ru/documents/203/18

Zharovska, H. P. (2019). Teoriia ta praktyka protydii transnatsionalnoii orhanizovanoii zlochynosti v Ukraini [Theory and practice of combating transnational organized crime in Ukraine]. dissertation ... Dr. jurid. science: 12.00.08. / National Academy of Internal Affairs. Kyiv.

Zelinskaia, N. A. (2006). Mezhdunarodnye prestupleniia i mezhdunarodnaia prestupnost [International crimes and international criminality]. Odesa: Yurydychna Literatura.

Zelinskaia, N. A. (2003). Politicheskie prestupleniya v sisteme mezhdunarodnoy prestupnosti [Political crimes in the international crime system]. Odesa: Feniks.

Ivanov, E. A. (1999). Otmyvanie deneg i pravovoe regulirovanie borby s nim [Laundering of money and legal regulation of the fight against it]. Moscow: Rossiiskii iuridicheskii izdatelskii dom.

Inogamova-Khegai, L. (2004). Poniatie prestupleniia i subekta prestupleniia po mezhdunarodnomu ugolovnomu pravu [The concept of a crime and a subject of a crime under international criminal law]. Ugolovnoe pravo, vol. 1, pp. 21-29.

Godson, R., \& Olson, W. (1995). International Organized Crime. Society. Jan.-Feb., pp. 155-157.

Gros, J.-G. (2003). Trouble in Paradise. Crime and Collapsed States in the Age of Globalization. British Journal of Criminology, vol. 43, no. 1, pp. 63-80.

Karpets, I. I. (1988). Mezhdunarodnaia prestupnost [International crime]. Moscow: Nauka.

Karpets, I. I. (1979). Prestupleniia mezhdunarodnogo kharaktera [International crimes]. Moscow: Iuridicheskaia literatura.

Cassese, A. (2005). International Criminal Law. Oxford: Oxford University Press.

Kibalnik, A. G. (2003). Sovremennoe mezhdunarodnoe ugolovnoe pravo: poniatie, zadachi i printcipy [Contemporary international criminal law: concept, objectives and principles]. Saint Petersburg: Iurtcentr Press.

Konventsiia Orhanizatsii Obiednanykh Natsii proty transnatsionalnoi orhanizovanoi zlochynnosti, ukhvalena Rezoliutsiieiu 55/25 Heneralnoi Asamblei vid 15 lystopada 2000 r. [United Nations Convention against Transnational Organized Crime, adopted by General Assembly Resolution 55/25 of November 15, 2000]. Available at: http:9/zakon.rada.gov.ua/laws/show/995_789

Konventsiia Orhanizatsii Obiednanykh Natsii pro borotbu proty nezakonnoho obihu narkotychnykh zasobiv i psykhotropnykh rechovyn vid 20 hrudnia 1988 r. [United Nations Convention against Illicit Traffic in Narcotic Drugs and Psychotropic Substances of December 20,1988]. Available at: https://zakon.rada.gov.ua/laws/ show/995_096

Konventsiia Orhanizatsii Obiednanyh Natsii proty koruptsii vid 31 zhovtnia 2003 r. [United Nations Convention against Corruption of October 31,2003]. Available at: https://zakon.rada.gov.ua/laws/show/995_c16

Konventsiia Rady Yevropy pro vidmyvannia, poshuk, aresht ta konfiskatsiiu dokhodiv, oderzhanykh zlochynnym shliakhom vid 8 lystopada 1990 r. [Council of Europe Convention on Laundering, Search, Seizure and Confiscation of the Proceeds of Crime of November 8, 1990]. Available at: https://zakon.rada.gov.ua/laws/ show/995_029\#Text

Konventsiia Rady Yevropy pro vidmyvannia, poshuk, aresht ta konfiskatsiiu dokhodiv, oderzhanykh zlochynnym shliakhom ta shchodo finansuvannia teroryzmu vid 16 travnia 2005 r. (SDRYe № 198) [Council of Europe Convention on Laundering, Search, Seizure and Confiscation of the Proceeds from Crime and on the Financing of Terrorism of May 16, 2005 (Council of Europe Treaty Series № 198)]. Available at: https://zakon.rada.gov.ua) laws/show/994_948

Konventsiia Rady Yevropy pro kiberzlochynnist vid 23 lystopada 2001 r. [Council of Europe Convention on Cybercrime of November 23, 2001]. Available at: https://zakon.rada.gov.ua/laws/show/994_575

Luneev, V. V. (2005). Prestupnost XX veka: mirovye, regionalnye i rossiiskie tendentcyy [Crime of the 20th century: global, regional and Russian trends] / second edition, revised and expanded. Moscow: Volters Kluver.

Mizhnarodna konventsiia shhodo borotby z pidrobkoiu hroshovykh znakiv vid 20 kvitnia 1929 r. [International Convention for the Suppression of Counterfeiting Banknotes, April 20, 1929]. Available at: https://zakon.rada.gov.ua/laws/show

Hrynchak, V. A., Zeman, I. V., Kohutych, I. I., \& Marin, O. K. (2019). Mizhnarodne kryminalne pravo (spivrobitnytstvo derzhav u protydii zlochynnosti) [International criminal law (cooperation of states in combating crime)]. Kharkiv: Pravo.

Butkevych, V. H. (ed.) (2004). Mizhnarodne pravo: osnovni haluzi [International law: main areas]. Kyiv: Lybid.

Mytsyk, V. V., Buromenskyi, M. V., Hnatovskyi, M. M. and others (2019). Mizhnarodne publichne pravo [International public law] textbook: in 2 volumes / vol. 1: Osnovy teorii. Kharkiv: Pravo.

Mytsyk, V. V., Buromenskyi, M. V., Hnatovskyi, M. M. and others (2019). Mizhnarodne publichne pravo [International public law] textbook: in 2 volumes / vol. 2: Osnovy teorii. Kharkiv: Pravo.

Pohoretskyi, M. A. (2007). Orhanizovana zlochynnist v Ukraini: tendentsii rozvytku ta zakhody protydii [Organized crime in Ukraine: development trends and countermeasures]. Borotba $z$ orhanizovanoiu zlochynnistiu $i$ koruptsiieiu, vol. 16, pp. 99-111. 
Popko, V. V. (2020). Transnatsionalne kryminalne pravo: mizhnarodno-pravovi zasady [Transnational criminal law: international legal principles]: dis. Doctor of Law in the speciality: 12.00.11 - International Law. Taras Shevchenko National University of Kyiv, Institute of International Relations. Kyiv.

Repetskaya, A. L. (2005). Transnatcionalnaia organizovannaia prestupnost: uchebnoe posobie [Transnational organized crime]. Irkutsk: BGUEP.

Rymskyi Statut Mizhnarodnoho kryminalnoho sudu vid 17 lypnia 1998 r. iz zminamy. Chynna redaktsiia vid 16 sichnia 2002 r. Dokument 995588 [Rome Statute of the International Criminal Court of July 17, 1998, as amended. Current version of January 16, 2002. Document 995_588]. Available at: http://zakon0.rada.gov.ua/ laws/show/995_588

Svensson, B. (1987). Ekonomicheskaia prestupnost [Economic crime]. Transl. from Swedish. Moscow: Progress. Shelley, L. I. (1995). Transnational Organized Crime: An Imminent Threat to the Nation-State? Journal of International Affairs., vol. 48, no. 2, Transcending National Boundaries. Winter 1995, pp. 463-489.

Skrylnyk, O. O., \& Slatvytska, A. V. (2011). Klasyfikatsiia zlochyniv u mizhnarodnomu pravi: teoretyko-pravovyi aspekt [Classification of crimes in international law: theoretical and legal aspect]. Forum prava, vol. 2, pp. 839-847. Available at: http://www.nbuv.gov.ua/e-journals/FP/20112/11 cootpa.pdf

Streltsov, Ye. L. (2000). Ekonomichni zlochyny: vnutrishnoderzhavni ta mizhnarodni aspekty [Economic crimes: domestic and international aspects]. Odesa: AstroPrynt.

Zelinska, N. A., Andreichenko, S. S., Dromina-Volok, N. V., \& Koval, D. O. (2017). Teoriia ta praktyka mizhnarodnoho kryminalnoho prava [Theory and practice of international criminal law]. Odesa: Feniks.

Chuprova, A. Yu. (2009). Transnatcionalnaia ekonomicheskaia prestupnost: voprosy protivodeistviia [Transnational economic crime: issues of counteraction]. Biznes $v$ zakone. Ekonomiko-iuridicheskii zhurnal. Yur-VAK, vol. 1, pp. 147-150. 